\title{
RELACJE INDYJSKO-RADZIECKIE W LATACH PIĘĆDZIESIĄTYCH I SZEŚĆDZIESIĄTYCH XX WIEKU
}

\begin{abstract}
Ekspansywna polityka sąsiadów - Pakistanu i ChRL - determinowała przywódcę Indii J. Nehru do zawarcia sojuszu, który zapewniłby gwarancje bezpieczeństwa jego krajowi. Pomimo aktywnej - sprzyjającej Indiom - polityki Waszyngtonu, realniejszy wydawał się sojusz z Moskwą. Sowieci akcentowali znaczenie przywództwa Indii w Ruchu Państw Niezaangażowanych. Oprócz założeń politycznych - o intensyfikacji kontaktów z Krajem Rad zdecydował również aspekt ekonomiczny. Głównym celem polityki wewnętrznej było wydobycie kraju z zapaści cywilizacyjnej. Nie byłoby to możliwe bez zapewnienia źródeł finansowania i inwestycji zagranicznych. Jednocześnie Indie musiały pozostać państwem niezależnym politycznie, dlatego pomoc gospodarcza miała ograniczać się tylko do aspektu ekonomicznego. Po przeanalizowaniu wielu czynników, będący u steru polityki zagranicznej dyplomaci przyjęli ostatecznie propozycję złożoną Indiom przez ZSRR. Zakładała ona wybudowanie - dzięki pomocy finansowej i przy wsparciu myśli technologicznej ZSRR zakładów przemysłu ciężkiego, rafinerii, przedsiębiorstw farmaceutycznych oraz instytucji naukowo-badawczych. W rezultacie pakistańskiego porozumienia z Zachodem, Moskwa zaczęła jednoznacznie wspierać indyjskie pretensje do Kaszmiru. Neutralizm indyjski poddany został poważnej próbie w przeddzień konfrontacji zbrojnej z armią chińską. Indie nie mogły liczyć nawet na moralne wsparcie Moskwy, która w przyszłym konflikcie z Indiami zdecydowana była poprzeć ChRL. Prestiżowa porażka Indii w konfrontacji z Chinami zaowocowała jednak reorganizacją i doinwestowaniem - dzięki wsparciu USA i ZSRR - indyjskich sił zbrojnych. Dzięki tym posunięciom, nieuchronnie zbliżająca się konfrontacja z Pakistanem miała duże szanse zakończyć się dla Indii sukcesem.
\end{abstract}

Słowa kluczowe: Jawaharlal Nehru, Indie, Związek Radziecki, Nikita Chruszczow, Ruch Państw Niezaangażowanych.

Na scenie teatru zimnowojennych zmagań, oprócz wrogich supermocarstw - aktorów pierwszoplanowych ról - nie brakowało także niedocenianych statystów. Historia zna jednak wyjątki od tej reguły. W wielu kluczowych momentach to liderzy państw Trzeciego Świata - wydawać by się mogło statyści w rozgrywkach politycznych imperiów przejmowali rolę reżyserów ingerujących w ustalony zawczasu scenariusz geopolitycznych rozgrywek. Rolę taką - na scenie konfrontacji politycznej bipolarnego świata - bez wątpienia odgrywały w tym czasie Indie.

Rozpatrując problematykę relacji indyjsko-radzieckich, warto wyodrębnić w niej dwa zasadnicze etapy: rządy premiera Jawaharlala Nehru (1947-1964) oraz okres sprawowania władzy przez jego następców: Gulzarilala Nanda (1964), Lala Bahadury Shastri'ego

\footnotetext{
${ }^{1}$ Dr Joanna Maj, Uniwersytet Łódzki, Instytut Historii, maj_joanna@wp.pl.
} 
(1964-1966) i Indiry Gandhi (1966-1977; 1980-1984). Ze względu na złożoność problematyki na szczególną uwagę zasługuje pierwsze stadium zdominowane politycznie doktryną nehruwianizmu². Zapoczątkowano wówczas współpracę indyjsko-radziecką w wymiarze zarówno politycznym, jak też gospodarczym i kulturalnym. Po śmierci premiera Nehru główne wyznaczniki indyjskiej polityki zagranicznej, w tym również względem ZSRR, nie zostały zaniechane i znalazły swoją kontynuację.

Celem określenia czynników, które wpływały na kształtowanie się powyższych relacji bilateralnych w założonym na wstępie przedziale chronologicznym, należy przeanalizować kilka zasadniczych aspektów:

1. Klimat zimnowojennej rywalizacji dwóch supermocarstw i związana z nim indyjska postawa niezaangażowania.

2. Aktywizacja polityki amerykańskiej w Azji i sojusz militarno-polityczny Waszyngtonu z wrogim Indiom Pakistanem (spór w sprawie przynależności Kaszmi$\mathrm{ru})$.

3. Charakter relacji na linii Moskwa - Pekin wpływający na intensyfikację stosunków indyjsko-radzieckich. Istotnym w tych okolicznościach aspektem było pozytywne nastawienie wielu polityków i inteligencji indyjskiej do idei socjalizmu.

Proklamowanie 15 sierpnia 1947 r. niepodległości Indii, determinowało rząd Jawaharlala Nehru do sformułowania głównych wyznaczników polityki zagranicznej nowego państwa. Uznano, że w obliczu zimnej wojny i rywalizujących dwóch supermocarstw jedynym realnym wyborem dla odrodzonego państwa będzie polityka niezaangażowania. Owo niezaangażowanie $w$ istocie oznaczało wyrzeczenie się siły, jako metody prowadzenia polityki międzynarodowej i stanowiło nawiązanie do hinduskiej tradycji wypracowanej w ciągu tysiącleci, a rozpowszechnionej w XX w. przez Mahatmę Gandhiego. Gandhyzm - neutralizm stanowił odtąd ideologiczną podbudowę suwerennego państwa indyjskiego $^{3}$. Koncepcję tę pojmowano jako rozwiązanie alternatywne wobec tragicznej wizji

${ }^{2}$ Nehruwianizm opiera się na poglądzie, że Indie są w stanie i w przyszłości będą dążyć do pokojowego współistnienia ze wszystkimi sąsiadami. K. Bajpai, Indian Strategic Culture, [w:] M. Chambers (red.), South Asia In 2020: Future Strategic Balances and Alliances, November 2002, s. 259, https://www.globalsecurity.org/military/library/report/2002/ssi_chambers.pdf (dostęp: 17 luty 2017).

${ }^{3}$ Mohandas Karamczand Gandhi przez świat zapamiętany jako Mahatma - Wielkoduszny - był postacią niewątpliwie unikatową. Działał na wielu płaszczyznach życia publicznego: politycznej, społecznej oraz moralnej. Nauczał aby podporządkować ideałom etycznym wszystkie dziedziny działalności ludzkiej. Już za życia stał się niewzruszonym autorytetem dla setek tysięcy ludzi. Nauki Gandhiego pod względem etycznym są głęboko zakorzenione w kulturze indyjskiej jako nauki dżainizmu, opierające się na trzech fundamentach: właściwej percepcji (samjagdarsana), właściwej wiedzy (samjagdżnana) oraz właściwym postępowaniu (samjagczaritra). Wymienione reguły weszły w skład kodeksu Gandhiego, który do historii przeszedł jako satyagraha. W naukach Gandhiego można wyodrębnić trzy postulaty i zagadnienia etyczne: egalitaryzm, ascetyzm, ahimsa. Wprawdzie w jego postulatach nie sposób odnaleźć innowacyjności na płaszczyźnie filozoficznej to jednak przeszedł on do historii dzięki wykorzystaniu dawnych dżaińskich wzorców. Kluczowym był fakt przeniesienia zasad moralnych do działalności politycznej. Trzeci obok egalitaryzmu i ascezy a zarazem najtrudniejszy w realizacji postulat dżainistów, który Gandhi chciał przenieść do działalności politycznej to ahimsa. Implikowała ona w sobie trzy zasady: przeciwdziałaniu złu, życzliwość dla przeciwnika, walki bez przemocy. Termin ahisma jest komplikacją słów sanskrytu: Himsa oznaczająca zło oraz przedrostka $a$. Stąd literaturze przedmiotu ahismę, a w konsekwencji całą satyagrahmę określa się ruchem biernego oporu. Sam 
wyniszczającego ludzkość konfliktu globalnego. Idea Gandhiego umożliwiała więc odcięcie się od tradycyjnej polityki mocarstwowej prowadzącej do osłabienia gospodarczego, zaś jej etyczne przesłanie pozwalało dyplomacji indyjskiej na akcentowanie swej niezależności i pragmatyzmu.

Koncepcja niezaangażowania nie ograniczała się jedynie do kształtowania ideologicznych i moralnych wzorców światopoglądowych. W Indiach rozumiano ją jako narzędzie w realizacji partykularnych celów i skupienia wszystkich wysiłków na rzecz utrzymania pokoju, wspierania antykolonializmu i walki z rasizmem ${ }^{4}$. Jej twórcy ufali, że przeciwwagę dla rywalizujących mocarstw mogły stanowić jedynie państwa postkolonialne z Azji i Afryki. Poprzez ścisłą współpracę miałyby szansę stworzyć tak zwana trzecią siłę na arenie międzynarodowej, indyferentną wobec konfliktu zimnowojennego. Siłą tą chciały kierować Indie - lider państw Trzeciego Świata. Na ten przykład Nehru - wyznając zasadę równych odległości z rywalizującymi supermocarstwami - oskarżał zarówno USA i ZSRR za utrzymywanie stanu zimnej wojny, określając dwa supermocarstwa mianem „pełnych grzechu i zła"5. Jednak - co warto podkreślić - w swej ocenie nie był do końca konsekwentny. W odróżnieniu od polityków z Waszyngtonu, władze na Kremlu miały być „,bardziej zdolne do odpokutowania, gdyż przynajmniej były nieskażone złem rasizmu i kolonializmu [sic! - przyp. aut.]"6.

\section{POCZĄTKI RELACJI INDYJSKO-RADZIECKICH}

Zainteresowanie Kremla nową sytuacją geopolityczną na subkontynencie azjatyckim uwidoczniło się dość wcześnie. Jeszcze tego samego dnia, kiedy to Indie ogłosiły swą niepodległość, Wiaczesław Mołotow w imieniu władz ZSRR wysłał depeszę do Jawaharlala Nehru z gratulacjami i z wyrazami życzliwości dla nowo powstałego państwa. 23 października 1947 r. Rosjanie mianowali na ambasadora w Indiach jednego z czołowych radzieckich dyplomatów - Kiriłła Wasiljewicza Nowikowa. Nehru odwdzięczył się z kolei nominacją na to samo stanowisko w Moskwie swojej siostry Vijayi Lakshmi Pandit $^{7}$. Te wstępne, raczej kurtuazyjne deklaracje sympatii nie miały jednak większego wpływu na reorientację doktryny politycznej Kremla. W radzieckich kołach rządzących podkreślano historyczne, polityczne i gospodarcze powiązania Indii z Brytyjską Wspólnotą Narodów. Strategicznym partnerem ZSRR w Azji pozostawała nadal Chińska Republika Ludowa. Zarówno w Moskwie, jak również w Pekinie mało pochlebnie odnoszono się do osoby Nehru, porównując go z ,indyjskim Czang Kaj-szekiem” i upatrując w nim sprzymierzeńca imperializmu zachodniego. Polityka niezaangażowania nie znajdowała uznania w oczach Stalina, który traktował neutralizm jako kamuflaż dla tzw. proimperialistycznych postaw ${ }^{8}$.

Gandhi odcinał się od takich określeń, optując przy definicji walki jako immanentnej cechy jego ruchu, ale bez użycia przemocy. I. Lazari-Pawłowska, Etyka Gandhiego, Warszawa 1958, s. $37-40$.

4 A.P. Rana, The Imperatives of Nonalignment. A Conceptual Study of India's Foreign Policy Strategy in the Nehru Period, New Delhi 1976, s. 226.

5 J. Nehru, India Today a Tomorrow, New Delhi 1959, s. 10.

${ }^{6}$ Ibidem.

${ }^{7}$ H. Roy, India and Soviet Union, Calcutta 1982, s. 9.

${ }^{8}$ Wedle relacji ambasadora radzieckiego w New Delhi K. Nowikowa na chłodne relację między Moskwą a New Delhi miał wpływ sojusz indyjski z blokiem amerykańsko-angielskim, dzięki 
Przełom w relacjach indyjsko-radzieckich nastąpił w połowie lat pięćdziesiątych. ZSRR zaniechał wówczas wspierania partii komunistycznych w różnych regionach Azji i począł zabiegać o nawiązanie stosunków dyplomatycznych z państwami Trzeciego Świata. Apel przywódcy Indii, o rozszerzenie idei niezaangażowania na terytoriach postkolonialnych, wygłoszony w kwietniu 1955 r. podczas konferencji w Bandungu, trafił na podatny grunt i tym samym spotkał się z uznaniem Nikity Chruszczowa ${ }^{9}$. W obliczu trudności, jakich przysparzała ZSRR sytuacja polityczna w Europie Środkowo-Wschodniej, odradzający się neutralizm był okazją rozszerzenia rywalizacji zimnowojennej i umocnienia wpływów politycznych na kontynentach azjatyckim i afrykańskim. Tym samym starano się odwrócić uwagę opinii międzynarodowej od spraw europejskich. Wzrastające poparcie i sympatie dla ruchów lewicowych w państwach Trzeciego Świata, Kreml zamierzał wykorzystać poprzez pozyskanie przychylności Indii - kraju cieszącego się ogromnym autorytetem wśród narodów walczących z kolonializmem. Wspólnotę interesów z ZSRR bardzo dobrze rozumiały elity polityczne New Delhi. Wsparcie Moskwy dla uzyskania przez Indie statusu lidera wśród państw rozwijających dawała możliwość oddziaływania na sprawy międzynarodowe.

Nie bez znaczenia dla intensyfikacji współpracy indyjsko-radzieckiej była również wzmożona aktywność polityki amerykańskiej w rejonie Azji. Przejawiała się ona między innymi powołaniem z inicjatywy Waszyngtonu dwóch paktów militarno-politycznych: SEATO $^{10}$ i Paktu Bagdadzkiego ${ }^{11}$. W przeciwieństwie do stanowiska radzieckiego, plany Białego Domu postrzegano przez pryzmat ingerencji w sprawy państw azjatyckich, przejawu neokolonializmu i negowania zasady samostanowienia narodów. Jednak kluczowym powodem krytycznego nastawienia New Delhi do inicjatywy amerykańskiej, było pozyskanie dlań Pakistanu ${ }^{12}$. Sojusz militarny Pakistanu z państwami zachodnimi - biorąc pod uwagę spór o przynależności Kaszmiru - był postrzegany jako największe zagrożenie dla

któremu Indie otrzymywały wsparcie w sprawie Kaszmiru i Hyderbrad. Nowikow twierdził, że on osobiście ma wielki szacunek do Nehru jako człowieka ale nie do Nehru jako premiera. Speech by Mr. K. P. S. Menon, Foreign Secretary to the Government of India on India's Foreign Policy at the Staff College, Wellington. http://www.php.isn.ethz.ch/collections/coll_india/Nehru Years-Introduction.cfm?navinfo=9631 (dostęp: 17 lutego 2017 r.).

http://www.php.isn.ethz.ch/collections/coll india/NehruYears-Introduction.cfm?navinfo=9631

9 Bandung, konferencja Krajów Azji i Afryki (18-24 kwietnia 1955). Dokumenty i materiały, Warszawa 1955

10 South-East Asia Treaty Organization (Pakt Południowo-Wschodniej Azji) powołany z inicjatywy USA na konferencji założycielskiej w Manili obradującej w dniach 6-8 września 1954 r. Oprócz USA do sojuszu przystąpiły: Australia, Nowa Zelandia, Filipiny, Francja, Tajlandia i Wielka Brytanii. Sygnatariusze zobowiązali się do wzajemnej współpracy i udzielenia sobie pomocy w przypadku agresji innego państwa, jak również przeciwstawiania się ekspansji komunizmu. Pełny tekst układu patrz: Zbiór Dokumentów, nr 9, 1954, s. 2206-2215.

11 Pierwszym krokiem w tworzeniu paktu był sojusz między Turcją a Pakistanem zawarty w kwietniu 1954 r., następnie Turcja zawała sojusz z Irakiem w kwietniu 1955 r., a we wrześniu tego roku kolejno przystąpiła do niego Wielka Brytania, Pakistan i Iran. W ten sposób powstał sojusz wojskowy, który przyjał nazwe od siedziby kwatery głównej w Bagdadzie. Pakt Bagdadzki. Dokumenty i materiaty, Warszawa 1956, s. 42-47.

12 J. Nehru's Speeches, vol. III (March 1953 - August 1957), New Delhi 1958, s. 319. 
Indii $^{13}$. Przywódca Indii nie mógł odebrać tej inicjatywy inaczej, jak tylko ewidentny dowód wrogich intencji USA. Nehru wprawdzie rozumiał, dążenia Amerykanów do przeciwdziałania wpływom radzieckim, jednakże akcentował dominujące jego zdaniem zagrożenie destabilizacją polityczną w rejonie południowej Azji: „Z pewnością - jak czytamy w jednym z jego przemówień - nikt nie może sobie wyobrazić, że rząd Pakistanu przystąpił do tego paktu z powodu zagrożenia uderzeniem militarnym Związku Radzieckiego. Zarówno środki przekazu, jak i oświadczenia kół rządowych w Pakistanie dały jasno do zrozumienia, że państwo to przyłączyło się do Paktu z powodu Indii. Czyżby tak bardzo obawiali się oni Indii? A może chcą się wzmocnić i jak się obecnie mówi - rozmawiać z pozycji siły. Niezależnie od tego wszystkiego przyłączyli się oni do Paktu Bagdadzkiego i SEATO głównie z powodu wrogiego nastawienia do nas"14.

\section{WSPÓŁPRACA POLITYCZNA}

Wprawdzie poczucie zagrożenia ze strony wzmocnionego sojuszem Pakistanu stało się głównym powodem zbliżenia indyjsko-radzieckiego, jednakże nie bez znaczenia okazały się osobiste sympatie premiera Indii do Kraju Rad. Nehru podziwiał ZSRR za rolę, jaką odegrał w krzewieniu światopoglądu Karola Marksa, z którym jako działacz niepodległościowy i socjalista utożsamiał przemiany społeczne i postęp cywilizacyjny, konieczny dla rozwoju i modernizacji Indii. Już w 1927 r. na zakończenie swej pierwszej podróży po Europie, Nehru postanowił wziąć udział w obchodach 10. rocznicy wybuchu Rewolucji Październikowej w Moskwie. Wizyta w ZSRR wpłynęła w znaczny sposób na rewizję jego dotychczasowego światopoglądu. Ze stolicy światowego proletariatu wyjechał pod wrażeniem postępu cywilizacyjnego i industrializacji, które nastąpiły po rewolucji, chociaż - jak później podkreślał - zabrakło wówczas refleksji nad kosztami społecznymi tak gwałtownych przemian ${ }^{15}$. Należy podkreślić, że wyniki ekonomiczne, pod wrażeniem których był wówczas Nehru, zawdzięczał ZSRR doktrynie gospodarczej Nowej Polityki Ekonomicznej, zapoczątkowanej jeszcze w 1921 r. i będącej częściowym powrotem do gospodarki rynkowej ${ }^{16}$.

Część radzieckich rozwiązań gospodarczych ukierunkowanych na uprzemysłowienie kraju pragnął Nehru zaszczepić na gruncie indyjskim. Swe teoretyczne rozważania rozwinął już rok po wizycie na Placu Czerwonym. Opublikował wówczas serię artykułów w poczytnych czasopismach indyjskich, a następnie zebrał je w jednej monografii, pod wspólnym tytułem Soviet Russia. Some Random Sketches and Impressions ${ }^{17}$.W tekstach

${ }^{13}$ Więcej informacji na temat konfliktu indyjsko-pakistańskiego: L. Blinkerberg, India - Pakistan. The History of Unsolved Conflicts, An Analysis of Some Structural Factors, Odense University Press 1998.

${ }^{14}$ Polityka zagraniczna Indii $w$ latach 1956-1958, dokumenty i bibliografia, opr. B. Mrozek, Warszawa 1956, s. 19.

${ }^{15}$ W 1938 r. Neru roku twierdził, że nie mógłby być komunistą głównie dlatego, ze ceni szeroki zakres osobistej wolności jednostki. W 1958 r. powtórzył tę wypowiedź, dodając, że „, komunizm stał się systemem napiętnowanym stosowaniem przemocy i wyrządzaniem ludziom krzywdy. Tak więc skażona została idea, którą komunizm zaproponował światu. Środki zniweczyły cel”. T. Mende, Conversation with Mr. Nehru, London 1956, s. 31-32.

16 R. Miedwiediew, Pod osąd historii. Geneza i następstwa stalinizmu, Warszawa 1990, s. 185-190.

17 J. Nehru, Soviet Russia. Some Random Sketches and Impressions, Allahabad Law Journal Press 1928. 
tych - oprócz akcentowanej fascynacji państwem Stalina - przyszły przywódca Indii wysuwał tezę o rozlicznych podobieństwach obu krajów. Zarówno Indie, jak też Rosja tuż po rewolucji zmagały się z tymi samymi problemami: ekstensywna gospodarka rolna, powolna industrializacja, powszechna bieda i analfabetyzm. Jednakże skoro ZSRR potrafił znaleźć rozwiązanie dla swoich problemów, tym bardziej Indie - wolne od zmory totalitaryzmu - powinny wykorzystać szansę na rozwój gospodarczy i cywilizacyjny ${ }^{18}$.

Głównym celem planu naprawczego Nehru stało się przeprowadzenie głębokich reform gospodarczych i wyprowadzenie kraju z zapaści ekonomicznej. Kontrast pomiędzy występującym w Indiach skrajnym ubóstwem i ekonomicznym zacofaniem był widoczny szczególnie $\mathrm{w}$ porównaniu $\mathrm{z}$ intensywnie rozwijającymi się państwami Zachodu. Jak wielokrotnie podkreślał: „W świecie nie ma politycznej rywalizacji między komunizmem a kapitalizmem, lecz istnieje rywalizacja między biednymi a bogatymi, między rozwiniętymi technologicznie a zacofanymi regionami świata"19. Kluczem do przezwyciężenia tych różnic miała być industrializacja, jednakże - co podkreślał - modernizacja gospodarki narodowej ,nie powinna być przeprowadzona w wyniku przyjęcia wolnorynkowego modelu ekonomicznego". W miejsce odrzucanego systemu kapitalistycznego przyjmowano „moralnie bardziej odpowiedni dla warunków indyjskich socjalizm” ${ }^{20}$.

W odróżnieniu od sektora prywatnego przynoszącego korzyści dla kapitału zagranicznego, wzrost gospodarki narodowej miały stymulować inwestycje w przemyśle państwowym: „Wybór - jak twierdził - może dotyczyć tylko jednej drogi, jest nią socjalizm. (...) Socjalizmu nie należy postrzegać jedynie przez pryzmat ekonomii, jest to filozofia życia i dlatego też przemawia do mnie najbardziej. Nie widzę innej drogi, by skończyć z ubóstwem, z powszechnym bezrobociem, które niszczy mój naród”21. Dla „Architekta Indii” uprzemysłowienie było jedyną realną drogą ekonomicznego rozwoju kraju, poprawy warunków życia najuboższych grup społecznych i wstąpienia na drogę rozwoju cywilizacyjnego: „Społeczeństwo powinno być bezklasowe, gospodarka planowana, a państwo ma za zadanie ograniczanie tych form własności, które zapewniają jednostkom niebezpieczną władzę nad społeczeństwem, nie pozwalając urzeczywistnić dążeń dla równych szans dla wszystkich",22.

Z początkiem lat pięćdziesiątych Indie wkraczały na drogę uprzemysłowienia, wdrażając jednocześnie ideę zwalczania kapitalizmu utożsamianego z władzami kolonialnymi. W 1950 r. Nehru powołał centralny organ gospodarczy - siedmioosobową Komisję Planowania a rok później ogłosił pierwszy plan pięcioletni (1951-1956). Istotnie, preferowano w Indiach politykę centralnego planowania ale nie ograniczano przy tym prywatnej działalności gospodarczej ${ }^{23}$. W jednym ze swoich przemówień wygłoszonych w $1958 \mathrm{r}$. Nehru twierdził, że nie opowiada się za państwem socjalistycznym w skrajnym tego słowa znaczeniu, gdzie kontroluje się wszystkie dziedziny życia i hamuje aktywność i inicjatywę jego obywateli ${ }^{24}$. W jego mniemaniu władze były zobligowane do kreowania polityki gospodarczej, ale w kooperacji z prywatnymi przedsiębiorcami. W myśl tych założeń

\footnotetext{
${ }^{18}$ Ibidem, India Today..., s. 5.

19 Ibidem, Autobiography, New Delhi 1936, s. 543.

20 Ibidem, The Discovery of India, New Delhi 1946, s. 474-475.

${ }^{21}$ Ibidem, India and the World, New Delhi 1936, s. 82-83.

22 T. Mende, Rozmowy z Nehru, Warszawa 1957, s. 150.

23 Ibidem, s. 28-29.

${ }^{24}$ Ibidem.
} 
sektor państwowy miał obejmować przemysł stoczniowy, telekomunikacyjny, hutniczy, górnictwo, energetykę atomową, kolej, zaś inne dziedziny miały być dostępne dla prywatnych jednostek gospodarczych. Rząd optował w ten sposób za wprowadzeniem mieszanego systemu ekonomicznego, z uwzględnieniem elementów prywatnej inicjatywy i sektora publicznego.

Pomimo pojawiających się zarzutów o kopiowanie stalinowskich wzorców, Nehru trwał w przekonaniu, że jego wizja reform ekonomicznych ma na celu odrzucenie zarówno komunizmu jak i kapitalizmu ${ }^{25}$. W tym kontekście reprezentował pogląd, iż przyłączenie się do jednego z bloków polityczno-wojskowych nie leży w interesie Indii. Opowiedzenie się po jednej ze stron konfliktu zimnowojennego czyniło możliwym jedynie jednostronną współpracę gospodarczą, a ponadto kłóciło się z zasadą pokojowego współistnienia ze wszystkimi państwami. Naturalne było więc dążenie Nehru do pozyskania wsparcia materialnego zarówno od USA, jak i ZSRR. Jednak z pobudek ideologicznych uważał, że korzystniejsze będzie nawiązanie ściślejszej współpracy z Moskwą. Będąc pragmatykiem nie miał wątpliwości, że centralizm zarządzania przedsiębiorstwami w ZSRR umożliwia sprawniejsze negocjacje niż długotrwałe rozmowy z amerykańskimi koncernami pozostającymi w rękach prywatnych: „Pragnę, by Indie mogły nadal prowadzić suwerenną politykę wewnętrzną i zagraniczną, a opowiedzenie się po stronie jednego z rywalizujących mocarstw będzie oznaczało ograniczenie tej wolności. Ponadto położenie geopolityczne Indii - graniczących z Chinami i oddalonych 20 mil od ZSRR czyni niezasadnym wspieranie Zachodu, gdyż sojusz z tymi krajami byłby przez Moskwę i Pekin źle odebrany"26. Wsparcie przemysłu radzieckiego było realną i konkretną propozycją Moskwy - w przeciwieństwie do Waszyngtonu, który to „pociągając za sobą kolejny wagon sieje wśród państw Azji niepokój i zamęt". Nie można przy tym bagatelizować faktu, że proradzieckie sympatie były powszechne wśród czołowych indyjskich polityków, w szczególności Kumara Padmanabha Sivasankara Menona i Triloki Nath Kaula ${ }^{27}$.

Pierwszym wyraźnym potwierdzeniem nowego otwarcia w relacjach indyjskoradzieckich było poparcie, którego udzieliło Indom ZSRR w sprawie porozumienia chińsko-indyjskiego z kwietnia 1954 r. Korzystając z okazji, jaką była piąta rocznica proklamowania ChRL, przebywający w Pekinie Nikita Chruszczow wygłosił deklarację, zawierającą główne wytyczne polityki zagranicznej reprezentowanych państw. W nawiązaniu do układu indyjsko-chińskiego przywódca radziecki stwierdził, że: „polityka ta odpowiada żywotnym interesom wszystkich państw w tym narodów Azji, których bezpieczeństwo i pomyślność mogą być zagwarantowane tylko w oparciu o wspólne wysiłki w obronie pokoju" 28 .

W następstwie rozmów dyplomatycznych, które prowadzono w Pekinie, pojawiły się dalsze propozycje Moskwy dotyczące nawiązania współpracy z Indiami. Według relacji

25 Ibidem, s. 15.

${ }^{26}$ M. Das, The Political Philosophy of Jawaharlal Nehru, London 1961, s. 202.

27 Triloki Nath Kaul (1913-2002) dyplomata, uważany za architekta polityki indyjskiej wobec ZSRR, kilkakrotnie pełnił funkcję ambasador a Indii w Moskwie: w latach 1947-1949, następnie 1962-1966 i 1986-1989. W 1973 r. Indira Gandhi mianowała go ambasadorem w USA. W swoich wspomnieniach opisuje historię stosunków Indii z ZSRR: A Diplomat's Diary 1947-99, Macmillan Publishers India Limited 2000. Ponadto autor kilku publikacji: Stalin to Gorbachov and Bayond, New Delhi 1991; Indo-Soviet Relations: Prospects and Problems, New Delhi 1991.

${ }^{28}$ Polityka zagraniczna Chińskiej Republiki Ludowej. Wybór dokumentów, J. Rowiński, E. Zysman, S. Kuczera (oprac.), cz. I: 1949-1954, Warszawa 1969, s. 333. 
nestora indyjskiego dziennikarstwa Durgi Dasa: „Sowieckie ministerstwo spraw zagranicznych natychmiast poprosiło naszego ambasadora w Pekinie, aby zaprosił Nehru do złożenia wizyty w Moskwie w drodze powrotnej z Chin. Nehru odpowiedział na to, że do Moskwy przyjedzie z oddzielną wizytą, a nie przy okazji, co wywołało w ZSRR wielkie zadowolenie" 29 .

W dniach od 7 do 22 czerwca 1955 r. J. Nehru przebywał z oficjalną wizytą w ZSRR. Rozmowy z przedstawicielami rządu radzieckiego dokonały zasadniczego zwrotu w stosunkach radziecko-indyjskich i przyczyniły się do zaprezentowania i omówienia stanowiska stron w najważniejszych kwestiach międzynarodowych. Strona radziecka zapewniła o swoim poparciu dla polityki zagranicznej niepodległych Indii, a Nehru pozyskał aprobatę Kremla w kwestii rozszerzenia Rady Bezpieczeństwa o siedmiu stałych członków z uwzględnieniem Indii i Chin ${ }^{30}$.

We wspólnym oświadczeniu podsumowującym tą wizytę przywódcy potwierdzili gotowość kształtowania stosunków na gruncie pokojowego współistnienia, które przyjęto na konferencji w Bandungu. W trakcie wygłaszanych przemówień podkreślano konieczność współpracy międzynarodowej państw na płaszczyźnie pokojowej bez względu na panujący w państwach system polityczny: „Nie ma żadnych powodów - stwierdzał Nehru podczas wystąpienia w Moskwie 21 czerwca 1955 r. - dla których kraje o różnych systemach politycznych, społecznych czy gospodarczych nie mogły współpracować pod warunkiem, że nie będą ingerowały nawzajem w swe sprawy i nie będą narzucały swej woli lub próbowały narzucić swego panowania”. Indie i ZSRR opowiedziały się również za zakazem stosowania broni jądrowej, a także za znaczącym ograniczeniem zbrojeń niekonwencjonalnych ${ }^{31}$. Wizyta premiera indyjskiego wzbudziła duże zainteresowanie opinii publicznej. Radziecka prasa pisała o wizycie Nehru bardzo szeroko a większość jego wstąpień została opublikowana.

Pobyt przywódcy Indii w ZSRR pobudził duże zainteresowanie kulturą indyjską. W Moskwie otwarto wystawę sztuki indyjskiej, na język rosyjski przetłumaczono książkę autorstwa Nehru The Discovery of India. Identyfikujący się z filozofią marksistowską autor tej poczytnej w Kraju Rad monografii, pozyskał dużą sympatię tamtejszych elit politycznych i - w przeciwieństwie do „natchnionego górnolotnymi ideami Gandhiego” postrzegany był za pragmatyka i faktycznego ojca niepodległych Indii. Pacyfistyczne poglądy Nehru - na skutek zaangażowania w pokojowe rozwiązanie konfliktu w Korei i Indochinach - nabrały również praktycznego wymiaru ${ }^{32}$.

Podtrzymując wzajemne kontakty w listopadzie 1955 r. delegacja radziecka na czele z N. Chruszczowem i Nikołajem Bułganinem przybyła z rewizytą do New Delhi. We wspólnym oświadczeniu potwierdzono zbieżność poglądów w sprawie Birmy, Indii i Afganistanu a także w kluczowych kwestiach ładu międzynarodowego i gotowości do

${ }^{29}$ D. Das, Indie od Curzona do Nehru i później, Warszawa 2009, s.338.

${ }^{30} \mathrm{~W}$ przeciwieństwie do propozycji radzieckiej oferta USA nie spotkała się z entuzjazmem w New Delhi. Zakładała ona pozbawienie Chin mandatu w Radzie Bezpieczeństwa na rzecz Indii. Nehru odbierał to jako próbę skonfliktowania Indii i ChRL.

${ }^{31}$ Zbiór Dokumentów, nr 6, 1955, s. 1286.

32 S.R. Sharma, India - USSR Relation, 1947-1971: From Ambivalence to Steadfastness, New Delhi 1999, s. 72. 
łagodzenia napięcia międzynarodowego. Potępiono przy tym politykę tworzenia agresywnych bloków wojskowych w Azji ${ }^{33}$.

Spotkania Nehru z czołowymi politykami radzieckimi, również w Indiach cieszyły się dużym zainteresowaniem. Zdawano sobie sprawę $\mathrm{z}$ ich kluczowego znaczenia w kontekście wzmocnienia pozycji politycznej państwa i jego przywódcy na arenie międzynarodowej. Oprócz dialogu politycznego zapoczątkowano również współpracę bilateralną na płaszczyźnie ekonomicznej. Osiągnięto między innymi porozumienie w sprawie rozszerzenia wzajemnych dostaw przemysłowych i zorganizowania regularnej komunikacji w oparciu o śródlądowe drogi wodne. Z kolei rozmowy prowadzone na linii Nehru Bułganin miały na celu wsparcie gospodarki indyjskiej nowoczesnymi technologiami ${ }^{34}$.

\section{WSPÓŁPRACA GOSPODARCZA}

Radziecka pomoc gospodarcza była niezwykle istotna ze względu na ogłoszenie przez rząd indyjski drugiego planu pięcioletniego $(1956-1961)^{35}$. Sowieci udzielili Indiom niskooprocentowanych pożyczek, dostarczyli nowoczesną infrastrukturę techniczną. Na prośbę Nehru do Indii przybyła grupa ekspertów radzieckich w celu przeszkolenia kadry kierowniczej, ponadto Rosjanie umożliwili wymianę personelu inżynieryjnego, który szkolono odtąd w ZSRR. Ważnym aspektem tego wsparcia było umożliwienie importu myśli technologicznej w dziedzinie metalurgii, przemysłu wydobywczego i elektronicznego ${ }^{36}$.

Współpraca gospodarcza kontynuowana była w następnych latach. W 1959 r. na zaproszenie rządu Indii do New Delhi przybyła delegacja rządowa Związku Radzieckiego ${ }^{37}$.

33 Ibidem.

34 Raport z rozmowy Bułganina i Chruszczowa z Nehru z 19 listopada 1955 r. sporządzony przez stronę indyjską (N.R. Pillai, K.P.S. Menon, S. Dutt) i radziecką (A. Gromyko i M.A. Mienszikow), http://www.php.isn.ethz.ch/collections/coll_india/NehruYears-Introduction.cfm? navinfo $=9631$.

35 Drugi plan pięcioletni realizowany był w latach 1956-1961. D. Rothermund, An Economic History of India, London 1993, s. 120-122; F. Franklel, India's Political Economy 1947-2004, Gradual Revolution, Delhi 2010.

36 Pomoc radziecka szczególnie uwidoczniła się w przemyśle ciężkim, zwłaszcza produkcji aluminium, co pozwoliło Indiom osiągnąć poziom produkcji tego surowca szacowany na 4000 ton rocznie. Dzięki radzieckim geologom, którzy uczestniczyli w opracowaniu mapy geologicznej Indii zwiększyły się szanse na rozwój indyjskiego programu wydobywczego surowców naturalnych, w szczególności ropy. W przemyśle elektronicznym, optycznym, budowie dróg kolejowych, radzieccy eksperci doradzali kierownictwu państwowych przedsiębiorstw. Biorąc pod uwagę założenia indyjskiego planu pięcioletniego, w którym za główny wyznacznik przyjęto industrializację plan ten był podobny do drugiego radzieckiego planu pięcioletniego. $\mathrm{Z}$ tych przyczyn w ZSRR ujawniają się tendencje do wspierania wysiłków indyjskich w drodze do budowy systemu socjalistycznego. Por. Raport Pilaii do V. T. Krishnamachari członka indyjskiej komisji planowania z 22 listopada 1955 r., http://www.php.isn.ethz.ch/collections/coll_india/ NehruYears-Introduction.cfm?navinfo $=9631$.

37 Wizyta trwała od 24 lutego do 19 marca W skład delegacji wchodzili: członek Prezydium Rady Najwyższej ZSRR M.A. Andrejew (szef delegacji), pierwszy zastępca przewodniczącego Rady Ministrów i minister spraw zagranicznych Gruzińskiej Socjalistycznej Republiki Radzieckiej M.I. Kuczawa, członek Komitetu Państwowego Rady Ministrów ZSRR do Spraw Stosunków Gospodarczych z Zagranicą A.G. Szeremietiew, oraz dyrektor Departamentu Azji południowej Minister Spraw Zagranicznych W.I. Lichaczow. Delegacji w czasie pobytu towarzyszyli: 
Ze zwiedzanych kombinatów przemysłowych, szczególnym zainteresowaniem gości cieszyły się zakłady wybudowane dzięki pomocy finansowej i przy wsparciu myśli technologicznej ZSRR - huta żelaza w Bhilai oraz Instytut Technologiczny w Bombaju ${ }^{38}$. W złożonym na ręce szefa rządu indyjskiego liście premier Chruszczow, zapowiedział dalszą pomoc finansową przy budowie rafinerii w Barauni oraz współpracę na rzecz rozwoju przemysłu farmaceutycznego. Kolejne porozumienia dotyczące współpracy gospodarczej, naukowej i kulturalnej podpisano w lutym 1960 r. oraz potwierdzono je podczas kolejnej wizyty Nehru w Moskwie we wrześniu 1961 roku $^{39}$.

Intensywność relacji indyjsko-radzieckich zaowocowała kolejnymi rewizytami radzieckich dygnitarzy. Po pięciu latach do Indii przybył ponownie przywódca ZSRR Nikita Chruszczow (luty 1960 r.). W opublikowanym po powrocie sprawozdaniu podkreślał on konstruktywizm rozmów z Nehru, a także przyjazną atmosferę i wyjątkową gościnność Indusów ${ }^{40}$. W wymiarze gospodarczym istotniejsze znaczenie miała wizyta radzieckiego premiera Aleksieja Kosygina (luty - marzec 1961 r.). Przewodniczący radzieckiego Gosplanu brał udział w posiedzeniach indyjskiej Komisji Planowania a także zwiedzał najważniejsze ośrodki przemysłowe ${ }^{41}$.

ambasador ZSRR w Indiach P.K. Ponomarenko, oraz ambasador Indii w ZSRR K.P.S. Menon. Zob.: Zbiór Dokumentów, nr 3, 1959, s. 341-344.

38 Ibidem.

39 Ibidem, nr 9, 1961, s. 1219-1227.

${ }^{40}$ Chruszczow podkreślał, że na indyjskiej farmie „czuł się jak u siebie w domu”, zaś ośrodek przemysłowy w Bhilai nazwał ,indyjskim Magnitogorskiem”. Owocem tej wizyty było podpisanie dwustronnej umowy dotycząca wymiany kulturalnej. Zgodnie z ustaleniami strony zobowiązały się rozwijać i rozszerzać współpracę kulturalną poprzez wzajemną promocję edukacji, sztuki, nauki i technologii. Umowa została ratyfikowana we wrześniu 1960 r. w Moskwie. Wiele imprez kulturalnych odbyło się w ramach obchodów 10. rocznicy proklamowania Republiki Indyjskiej. W teatrach wystawiano sztuki indyjskie, projekcje filmów indyjskich. Wydawano książki autorów indyjskich. S.R. Sharma, op. cit., s.79.

${ }^{41}$ Pod koniec października, kiedy produkcja stali w Bhilai przekroczyła poziom 365 ton, w radzieckiej „Prawdzie” opublikowano serię artykułów, o wymownych tytułach: „Bhilai - symbolem nowej przyszłości wielkich Indii”, „Współpraca indyjsko-radziecka - wielką rzeczą” Na dowód tych stwierdzeń gazeta przytoczyła dane dotyczące poziomu produkcji w Bhilai: 815 tys. ton żelaza, 260 tys. ton stali, 920 tys. ton koksu.

Wiele z informacji na temat współpracy gospodarczej radziecko-indyjskiej przybliża raport ambasadora indyjskiego w Moskwie Vengalil Krishnan Krishna Menona. Menon dokonując analizy pomocy gospodarczej ZSRR dla Indii, równocześnie podkreśla znaczący jej wpływ na modernizację indyjskiej gospodarki. I tak na ciężki sprzęt budowlany i maszyny górnicze eksportowane do Indii po 1957 r. rząd radziecki udzielił kredytu w wysokości 500 milionów rubli. W czerwcu 1959 r. Moskwa zaproponowała Indiom kredyt w wysokości 1500 milionów rubli, by wesprzeć trzeci plan pięcioletni. Kredyt wykorzystano na modernizację gospodarki indyjskiej. Dzięki tym inwestycjom wydajność kombinatu metalurgicznego w Bhilai wzrosła do 2,5 miliona ton rocznie. Ponadto w Indiach swoiste prosperity przeżywał przemysł wydobywczy ropy naftowej i gazu ziemnego. Kolejne kredyty w wysokości 500 milionów rubli napłynęły do Indii do końca lipca 1960 r. Środki te przeznaczono na wspieranie rozwoju przemysłu naftowego w Cambay i Ankleswar oraz na realizację projektu budowy elektrowni wodnej w Bhakra i rafineri w Gujarat. Raport ambasadora Indii w Moskwie Menona z 5 stycznia 1961 r., http://www.php.isn.ethz. $\mathrm{ch} /$ collections/coll_india/NehruYears-Introduction.cfm?navinfo=9631; B.N. Banerjee, India's Political Unity and Soviet Foreign Policy, New Delhi 1985, s. 188-202. 
Na skutek widocznego ożywienia w kontaktach gospodarczych obu krajów, nie mniej intensywnego charakteru nabrała również współpraca polityczna. Przywódcy Indii i ZSRR wypracowali wspólne stanowisko wobec faktu zawiązania bloków polityczno-militarnych w Azji - SEATO i Paktu Bagdadzkiego a także aktywności na tym polu rządu z Karaczi. W rezultacie pakistańskiego porozumienia z Zachodem, Moskwa zaczęła jednoznacznie wspierać indyjskie pretensje do Kaszmiru. Delegat radziecki w Radzie Bezpieczeństwa ONZ oskarżał państwa zachodnie o ,planowanie przeistoczenia Kaszmiru w militarną machinę skierowaną przeciwko ZSRR i ChRL"42. Tymczasem dyplomacja radziecka konsekwentnie określała sporny region, jako „niezbywalną część Indii” i wspierała na forum Narodów Zjednoczonych każde indyjskie stanowisko w tej sprawie. Kiedy w latach 1957 i 1962 - w obliczu wzmożonej aktywności armii pakistańskiej na terytorium Kaszmiru - kwestia przynależności tego terytorium powróciła do debaty w Radzie Bezpieczeństwa, Związek Radziecki wetował te z rezolucji Rady, które miały niekorzystny dla New Delhi wydźwięk ${ }^{43}$.

Wsparcie dla polityki New Delhi na subkontynencie indyjskim, czyniło z Indii zadeklarowanego sojusznika Moskwy. Relacje te zostały uwypuklone w swoistej niekonsekwencji działań i wybiórczej aktywności dyplomacji indyjskiej w odniesieniu do poszczególnych konfliktów międzynarodowych. Wyraźnie dało się zauważyć, że z jednej strony Indie dość pobłażliwie podchodziły do radzieckiej dominacji w krajach Europy Środkowo-Wschodniej, z drugiej zaś wszczynały - pod hasłem walki z neokolonializmem - ostrą krytykę poczynań Zachodu na Bliskim Wschodzie. Taka postawa uwidoczniła się w kontekście dwóch kluczowych wydarzeń roku 1956: interwencji radzieckiej na Węgrzech i kryzysu sueskiego.

Nehru nie ukrywał swego oburzenia polityką Zachodu wobec Egiptu. Niezwłocznie po ataku na to państwo sprzymierzonych wojsk Izraela, Francji i Wielkiej Brytanii wystosował notę do Sekretarza ONZ, w której sygnalizował duże zaniepokojenie Indii i apelował, o podjęcie przez ONZ natychmiastowych działań umożliwiających zakończenie konfliktu. Odmienne stanowisko Indie przyjęły wobec wydarzeń węgierskich. Dyplomaci indyjscy konsekwentnie odmawiali komentarzy w tej sprawie. Podczas głosowania 10 stycznia 1957 r. nad rezolucją domagającą się od ZSRR wycofania wojsk z Węgier ${ }^{44}$, misji obserwatorów ONZ i przeprowadzenia demokratycznych wyborów, delegat indyjski K. Menon wystosował głos przeciwny, uznając że podjęcie tych postulatów byłoby jednoznaczne $\mathrm{z}$ ingerencją w sprawy wewnętrzne Węgierskiej Republiki Ludowej ${ }^{45}$.

\section{W OBLICZU KONFLIKTÓW ZIMNOWOJENNYCH}

Wsparcie Indii dla polityki Związku Radzieckiego przybrało na początku lat sześćdziesiątych wyraźnego charakteru ideologicznego. Premier Nehru odnosząc się do kolejnych incydentów wywołanych konfliktem zimnowojennym - szczególnie w związku

42 S. Gupta, Kasmir: A Study in India - Pakistan Relations, Bombay 1967, s. 244.

${ }^{43}$ V. Schofield, Kashmir in Conflict, India, Pakistan and the Unending War, London 2003, s. 85.

${ }^{44}$ Interwencja ZSRR na Węgrzech została oprotestowana przez USA na forum ONZ. Wobec veta ZSRR Rada Bezpieczeństwa nie mogła podjąć decyzji, dlatego też 12 listopada 1956 r. sprawę przekazano do Zgromadzenia Ogólnego. A. Czubiński, W. Olszewski, Historia powszechna 1939-1997, Poznań 1999, s. 330.

45 R.N. Berkers, M.S. Bedi, The Diplomacy of India. Indian Foreign Policy in the United Nations, London 1948, s. 48. 
z zestrzeleniem nad ZSRR amerykańskiego samolotu rozpoznawczego Lockheed U-2 i kryzysu na Bliskim Wschodzie - winą za ich inspirowanie obarczał wyłącznie USA. $\mathrm{W}$ porównaniu $\mathrm{z}$,bezwzględną postkolonialną strategia polityczną Białego Domu”, Kreml - w ocenie Neru - jawił się w podwójnej roli: „bojownika walczącego z imperializmem i obrońcy światowego pokoju". Niemały wpływ na ugruntowanie światopoglądu swojego przywódcy wywarli analitycy i pracownicy dyplomatyczni zatrudnieni w placówce w Moskwie. Z ambasady szerokim strumieniem napływały raporty i sprawozdania opisujące cele i gloryfikujące sukcesy polityki wewnętrznej i międzynarodowej ZSRR. Często przybierały one formę „,wybielania” motywów postępowania Moskwy w realiach odwilży zimnowojennej ${ }^{46}$.

Pozytywnie kształtujące się relacje indyjsko-radzieckie - w kontekście konfliktu z Pakistanem o Kaszmir i znacznego ochłodzenia stosunków tych państw z ChRL - stawiały Indie na pozycji uprzywilejowanej ${ }^{47}$. Fakt ten stanowił istotny argument w zbliżającej się nieuchronnie konfrontacji z Pekinem. Jej genezy należy upatrywać we wsparciu, jakiego udzieliły Indie Tybetańczykom w marcu 1959 roku. Krwawo stłumione przez armię chińską powstanie w Tybecie i exodus Dalajlamy XIV, odbiły się szerokim echem wśród poruszonej tym faktem indyjskiej opinii publicznej. Udzielenie schronienia na terytorium Indii tybetańskiej emigracji politycznej, stało się synonimem solidarności Indusów z dążeniami wolnościowymi tego narodu, co naturalnie spotkało się z krytyką Pekinu. W tej napiętej już sytuacji międzynarodowej kwestia nieuregulowanej indyjskochińskiej granicy himalajskiej okazała się pretekstem do wszczęcia interwencji zbrojnej ${ }^{48}$.

W rozmowach dyplomatycznych nad uregulowaniem kwestii granicznej strony konfliktu próbowały pozyskać wsparcie Kremla. Wprawdzie w oficjalnych komunikatach Sowieci deklarowali neutralizm, zapewniając jednocześnie Pekin o swym zrozumieniu dla kwestii tybetańskiej, jednakże nie omieszkali rozpowszechniać ukazujące się w zachodnich mediach doniesienia piętnujące chińską brutalność podczas pacyfikacji Tybetu. W tym samym czasie Rosjanie udzielili Indiom kolejnego kredytu w wysokości 375 milionów dolarów z zastrzeżeniem, że środki te nie będą wykorzystane na zakup uzbrojenia ${ }^{49}$.

W obliczu eskalacji konfliktu granicznego Indusi zainicjowali rozmowy, których celem było pozyskanie pomocy militarnej od ZSRR. W połowie października $1960 \mathrm{r}$. do Moskwy przybyła delegacja wojsk lądowych Indian Army i lotnictwa. Negocjacje zakończyły się sukcesem i sfinalizowane zostały podpisaniem umowy na dostarczenie ośmiu samolotów AN-12, przystosowanych do transportowania ciężkiego sprzętu ${ }^{50}$. W toku dalszych wypadków, wobec napiętej sytuacji na granicy z Chinami pozyskanie sprzętu

${ }^{46}$ Raport Menona ambasadora w Moskwie z 31 lipca 1960 r., http://www.php.isn.ethz.ch/ collections/coll_india/NehruYears-Introduction.cfm?navinfo=9631.

47 Symptomy pogarszających się relacji radziecko-chińskich należy upatrywać w 1958 r., kiedy Chruszczow odmówił wsparcia dla chińskiego programu nuklearnego. Równie mocno krytykowane było przez Chiny nawiązanie dialogu na linii Chruszczow - Eisenhower. Szerzej na ten temat: D.S. Zagoria, The Sino-Soviet Conflict, 1956-1961, Princeton 1962.

48 Temat wojny indyjsko-chińskiej podjęty został przez autorkę w monografii: Spór graniczny chińsko-indyjski z 1962 roku a dyplomacja Stanów Zjednoczonych Ameryki, Toruń 2011.

${ }^{49}$ Raport Menona ambasadora w Moskwie z 5 stycznia 1961 r., http://www.php.isn.ethz.ch/ collections/coll_india/NehruYears-Introduction.cfm?navinfo=9631.

${ }^{50}$ Całkowity koszt kontraktu wyniósł 100 milionów rupii. Ponadto strona radziecka zobowiązała się do przeszkolenia personelu obsługującego samoloty AN-12. Ibidem. 
transportowego okazało się jednak dalece niewystarczające. Indie rozpoczęły więc ponowne negocjacje z Rosjanami o zakup nowoczesnych samolotów myśliwskich MIG 21. Ponadto wysiłki administracji Nehru oscylowały wokół pozyskania radzieckich doradców, którzy podjęliby się zadania modernizacji indyjskich sił powietrznych. Nehru był pewien, że - w przeciwieństwie do państw zachodnich - strona radziecka nie będzie narzucać żadnych warunków w związku z wykorzystaniem jej myśli technologicznej, czy też domagać się od Indii przystąpienia do sojuszu wojskowego ${ }^{51}$. Zgodnie z tymi przewidywaniami New Delhi zaproponowano dogodne warunki realizacji i finansowania kontraktu. Transakcja miała być rozliczona w rupiach, co w trudnej sytuacji gospodarczej Indii było niezwykle istotne. Ponadto ZSRR oferował dogodne warunki płatności i dostawy sprzętu w terminie. Argumentem przemawiającym za przyjęciem oferty ZSRR były również kwestie prestiżowe. Politycy indyjscy konsekwentnie realizując zasadę neutralizmu podkreślali, że mają możliwość zakupu uzbrojenia od państw dwóch przeciwstawnych bloków.

Napięta sytuacja międzynarodowa początku lat sześćdziesiątych pokrzyżowała klarowne plany Nehru. Rywalizacja indyjsko-chińska w Himalajach zbiegła się w czasie z tajnym rozmieszczeniem przez ZSRR na Kubie pocisków balistycznych średniego za$\mathrm{sięgu}^{52}$. W zaistniałej sytuacji Kreml rozpoczął dyplomatyczne zabiegi o pozyskanie wsparcia ChRL. Dla Pekinu swoistym probierzem intencji północnego sąsiada były wydarzenia zapoczątkowane 8 października 1962 r., gdy do Moskwy dotarła nota z informacją, że na agresję wojsk indyjskich Chiny odpowiedzą zbrojnie. Kiedy kilka dni później chińscy politycy dyskutowali nad zatwierdzeniem terminu rozpoczęcia wojny, z ZSRR nadeszły wyczekiwane sygnały poparcia. Chiński ambasador w Moskwie Liu Xiao, otrzymał od N. Chruszczowa zapewnienie o poparciu Chin w sporze z Indiami. W tej sytuacji formalnością była deklaracja Pekinu odwzajemniająca gest Kremla wsparciem dla radzieckiej polityki w sytuacji narastającego kryzysu kubańskiego ${ }^{53}$. Liu Xiao został zapewniony, że w przyszłym konflikcie z Indiami strona radziecka poprze ChRL, natomiast dostarczenie Indiom wyczekiwanych myśliwców ulegnie opóźnieniu. Na pocieszenie w listopadzie 1962 r., Chruszczow zapewnił New Delhi w lakonicznie brzmiącym komunikacie, że bez względu na stosunki indyjsko-chińskie, kontrakt dotyczący samolotu MIG-21 będzie nadal honorowany.

${ }^{51}$ The Sino-Indian Border Dispute. Section 3: 1961-1962, DD/I Staff Study, CIA/RSS, Reference Title Polo XVI, 5 May 1964, www.foia.cia.gov/CPE/POLO/polo-09.pdf

${ }^{52}$ Kryzys Kubański (15-28 października 1962 r.) jeden z najpoważniejszych kryzysów politycznych w historii międzynarodowych stosunków po II wojnie światowej, związany z zainstalowaniem sowieckich rakiet na terytorium Kuby. 22 października prezydent J.F. Kennedy wygłosił dramatyczne przemówienie telewizyjne o zagrożeniu półkuli zachodniej. N. Chruszczow początkowo zaprzeczał obecności ofensywnej broni sowieckiej na Kubie. 24 października po wprowadzeniu przez USA blokady morskiej wyspy i skierowaniu do ZSRR żądania wycofania rakiet, obie strony postawiły w stan najwyższej gotowości atomowe siły strategiczne, co groziło wybuchem wojny jądrowej. W dialogu między mocarstwami pośredniczył sekretarz generalny ONZ Sithu U Thant. 27 października po wymianie listów między Kennedym a Chruszczowem, nastąpił przełom - ZSRR ostatecznie zgodził się na usunięcie rakiet w zamian za amerykańską gwarancje bezpieczeństwa dla Kuby i obietnicę wycofania amerykańskich rakiet z Turcji. Szerzej na ten temat: L.H. Brune, The Missile Crisis of October 1962: A Review of Issues and References, Claremont 1985.

53 The Sino-Indian border Dispute... 
Kryzys kubański i wojna z Chinami poddała neutralizm indyjski poważnej próbie. W przeddzień konfrontacji zbrojnej z armią chińską Indie nie mogły liczyć nawet na moralne wsparcie Moskwy. Na próżno nowo mianowany ambasador Indii w Moskwie T.N. Kaul szczegółowo informował stronę radziecką o zajściach na granicy z Chinami podkreślając ekspansywne zamiary Pekinu. Już 25 października moskiewska „Prawda” opublikowała artykuł oskarżający New Delhi o „fałszywą interpretację granicy i celowe działanie na szkodę Chin, inspirowane podszeptami zachodnich imperialistów"54. Przywódca Indii nie krył swego rozczarowania krótkowzroczną - jak twierdził - polityką sowietów. W tych trudnych chwilach zaowocować miała koncepcja równych odległości wobec rywalizujących bloków militarnych. Prywatne sympatie Nehru dla Kraju Rad odeszły do lamusa historii. Zwyciężyć miał pragmatyzm.

Krytycznego dnia 25 października 1962 r., kiedy to indyjski front załamał się w okolicy Tawang, Nehru skierował do przywódców mocarstw apel, zabiegając o moralne i materialne wsparcie $\mathrm{w}$ walce $\mathrm{z}$ agresorem ${ }^{55}$. Na odpowiedź Zachodu nie trzeba było długo czekać. 29 października prezydent USA John Fitzgerald Kennedy, w liście skierowanym do Nehru, potwierdził gotowość współpracy: „Macie naszą sympatię - pisał - i z całego serca popieramy was w tej sytuacji. Jesteśmy pod wrażeniem waszej imponującej cierpliwości w postępowaniu z Chińczykami" ${ }^{56}$. W listopadzie 1962 r., Biały Dom podjął decyzję o wysłaniu do Indii misji wojskowej na czele z Averellem Harrimanem ${ }^{57}$. Jej celem było oszacowanie indyjskich potrzeb obronnych i ustalenie rozmiaru pomocy militarnej ${ }^{58}$. Tuż po zwieszeniu broni w listopadzie 1962 r. do Indii dotarła amerykańska pomoc wojskowa. Zaangażowanie USA w rozwiązanie sporu granicznego indyjsko-chińskiego wyraźnie zaniepokoiło Moskwę i skłoniło do wywiązania się z podjętych obietnic - w styczniu 1963 r. Indian Air Force wzbogaciło się o sześć samolotów MIG-21. Prestiżowa porażka Indii w konfrontacji z Chinami zaowocowała jednak reorganizacją i doinwestowaniem - dzięki wsparciu USA i ZSRR - indyjskich sił zbrojnych. Dzięki tym posunięciom nieuchronnie zbliżająca się konfrontacja z Pakistanem miała duże szanse zakończyć się dla Indii sukcesem ${ }^{59}$.

Nehru do końca swoich dni nie szczędził słów goryczy pod adresem ZSRR. Postawę dotychczasowego partnera podczas wojny 1962 roku odbierał osobiście, jako sprzeniewierzenie się wypracowanej przez lata zasadzie pokojowego współistnienia. Jednak przychylna Moskwie polityka kontynuowana była nadal przez jego następców: Gulzarilala Nanda, Lala Bahadurę Shastriego i Indirę Gandhi. Należy przy tym podkreślić, że Związek Radziecki wywiązywał się z wcześniejszych ustaleń i realizował program pomocy gospodarczej dla Indii. W czasie konfliktu zbrojnego z Pakistanem dyplomacja radziecka aktywnie zaangażowała się $\mathrm{w}$ jego rozwiązanie, doprowadzając $\mathrm{z}$ inicjatywy premiera

54 Ibidem.

55 Letter from Prime Minister Nehru to President Kennedy, New Delhi, April 21, 1963 [w:] FRUS, 1961-1963, Vol. XIX, South Asia, Document 279, DC: Government Printing Office, Washington 1996, s. 552.

56 Telegram from the Departament of State to the Embassy In India, 28 October 1962, http://www.state.gov/r/pa/ho/frus/kennedyjf/46453.htm, s.187.

57 (William) Averell Harriman (1891-1986), polityk, dyplomata i biznesmen amerykański, w latach 1943-1946 ambasador USA w ZSRR. Za prezydentury L. Jonhsona ambasador do specjalnych misji.

58 R. Hilsman, To Move a Nation, New York 1967, s. 328.

${ }^{59}$ B.C. Chakravorty, D. Phil, History of the Indo- Pak War 1965, New Delhi 1992. 
Kosygina do konferencji w Taszkiencie (styczeń 1966 r.). Radziecki przywódca występując $\mathrm{w}$ roli rozjemcy uczestniczył w rozmowach z prezydentem Pakistanu Ayub Khanem i premierem Indii L.B. Shastrim, co w efekcie pozwoliło wypracować tzw. Deklarację Taszkiencką ${ }^{60}$. Od połowy lat sześćdziesiątych można mówić o zawiązaniu się nieformalnych przymierzy, na których opierała się polityka dwóch największych rywali subkontynentu indyjskiego. Pakistan pozyskał dla swych planów USA i Chiny, Indie z kolei wspierane były przez ZSRR. Sojusze te ukształtowały się formalnie do $1971 \mathrm{r}$. Wówczas to Moskwa i New Delhi zawarły na dwadzieścia lat Traktat o Pokoju Przyjaźni i Współpracy (Treaty of Peace, Friendship and Cooperation) ${ }^{61}$.

Podjęta na przełomie lat pięćdziesiątych i sześćdziesiątych XX w. współpraca indyjsko-radziecka okazała się dla obu stron bardzo korzystna. Wkraczała w kluczowe sfery życia społecznego i była podyktowana wieloma praktycznymi względami:

1. Związek Radziecki próbując umocnić swoje wpływy w regionie Trzeciego Świata, dążył do współdziałania z Indiami, kraju pretendującego do roli lidera wśród państw postkolonialnych.

2. Współpraca indyjsko-radziecka oscylowała wokół napiętej sytuacji na subkontynencie indyjskim. Składała się na nią aktywizacja polityki amerykańskiej i tym samym powołanie paktów militarno-politycznych SEATO i Paktu Bagdadzkiego oraz dążenie Pekinu do pomniejszenia roli Indii w regionie.

Spory terytorialne z Pakistanem i Chinami, obligowały premiera Nehru do pozyskania silnego sprzymierzeńca i pomimo propozycji docierających z Waszyngtonu, najbardziej pożądanym sojusznikiem był ZSRR. Sowieci nie wymagali politycznych deklaracji lojalności, co współgrało z ideą niezaangażowania lansowaną przez Indusów. O ukierunkowaniu polityki zagranicznej New Delhi pod kątem współpracy z Krajem Rad zdecydował również aspekt ekonomiczny. Głównym zadaniem indyjskiej klasy politycznej było wydobycie kraju z zapaści cywilizacyjnej. Stąd potrzeba nowych źródeł finansowania i inwestycji zagranicznych. Zdaniem Nehru, Indie musiały pozostać państwem niezależnym politycznie, dlatego pomoc gospodarcza miała ograniczać się tylko do aspektu ekonomicznego. Oferta Moskwy okazała się pod tym względem bezkonkurencyjna.

\section{LITERATURA}

[1] Berkers R.N., Bedi M.S., The Diplomacy of India. Indian Foreign Policy in the United Nations, London 1948.

[2] Bandung, konferencja Krajów Azji i Afryki (18-24 kwietnia 1955). Dokumenty i materiały, Warszawa 1955.

[3] Blinkerberg L., India-Pakistan. The History of Unsolved Conflicts, An Analysis of Some Structural Factors, Odense University Press 1998.

[4] Chakravorty B.C., Phil D., History of the Indo- Pak War 1965, New Delhi 1992.

[5] Das M., The Political Philosophy of Jawaharlal Nehru, London 1961.

[6] Das D., Indie od Curzona do Nehru i później, Warszawa 2009.

[7] Franklel F., India's Political Economy, 1947-2004, Gradual Revolution, Delhi 2010.

${ }^{60}$ Dziewięciopunktowa deklaracja taszkiencka podpisana 10 stycznia $1966 \mathrm{r}$. określała m.in. normalizację stosunków dwustronnych, pokojowe rozwiązywanie sporów i wycofanie wojsk na pozycję sprzed działań zbrojnych z 1965 roku

${ }^{61}$ H.M. Verna, India and World Affairs. Foreign Policy of India, New Delhi, s. 134-138. 
[8] Gupta S., Kasmir: A Study in India - Pakistan Relations, Bombay 1967.

[9] Hilsman R., To Move a Nation, New York 1967.

[10] Kaul T.N., Indo-Soviet Relations: Prospects and Problems, New Delhi 1991.

[11] Lazari-Pawłowska I., Etyka Gandhiego, Warszawa 1958.

[12] Letter from Prime Minister Nehru to President Kennedy, New Delhi, April 21, 1963 [w:] FRUS, 1961-1963, vol. XIX, South Asia, Document 279, DC: Government Printing Office, Washington 1996.

[13] Maj J., Spór graniczny chińsko-indyjski z 1962 roku a dyplomacja Stanów Zjednoczonych Ameryki, Toruń 2011.

[14] Nehru J., Autobiography, New Delhi 1936.

[15] Nehru J., The Discovery of India, New 1946.

[16] Nehru J., India Today a Tomorrow, New Delhi 1959.

[17] Nehru J., India and the World, New Delhi 1936.

[18] Nehru J., Soviet Russia. Some Random Sketches and Impressions, Allahabad Law Journal Press 1928.

[19] Nehru's Speeches, Vol. III (March 1953 - August 1957), New Delhi 1958.

[20] T. Mende, Conversation with Mr. Nehru, London 1956.

[21] Pakt Bagdadzki. Dokumenty i materiaty, Warszawa 1956.

[22] Polityka zagraniczna Chińskiej Republiki Ludowej. Wybór dokumentów, J. Rowiński, E. Zysman, S. Kuczera (oprac.), cz. I: 1949-1954, Warszawa 1969.

[23] Polityka Zagraniczna Indii w latach 1956-1958, dokumenty i bibliografia, opr. B. Mrozek, Warszawa 1956.

[24] Rana A.P., The Imperatives of Nonalignment. A Conceptual Study of India's Foreign Policy Strategy in the Nehru Period, New Delhi 1976.

[25] Rothermund D., An Economic History of India, London 1993.

[26] Roy H., India and Soviet Union, Calcutta 1982.

[27] Schofield V., Kashmir in Conflict, India, Pakistan and the Unending War, London 2003.

[28] Sharma S.R., India - USSR Relation, 1947-1971:From Ambivalence to Steadfastness, New Delhi 1999.

[29] Verna H.M., India and World Affairs. Foreign Policy of India, New Delhi.

[30] Zbiór Dokumentów, Polski Instytut Spraw Międzynarodowych.

[31] Bajpai K., Indian Strategic Culture [w:] South Asia In 2020: Future Strategic Balances and Alliances, ed. M. Chambers, November 2002, https://www.globalsecurity.org/ military/library/report/2002/ssi_chambers.pdf.

[32] Speech by Mr. K.P.S. Menon, Foreign Secretary to the Government of India on India's Foreign Policy at the Staff College, Wellington. http://www.php.isn.ethz.ch/collections/ coll_india/NehruYears-Introduction.cfm?navinfo $=9631$.

[33] Raport z rozmowy Butganina i Chruszczowa z Nehru z 19 listopada 1955 r. sporzadzony przez stronę indyjska (N.R. Pillai, K.P.S. Menon, S. Dutt) i radziecka (A. Gromyko i M.A. Mienszikow).

http://www.php.isn.ethz.ch/collections/coll_india/NehruYearsIntroduction.cfm?navinfo $=9631$.

[34] Raport Pilaii do V. T. Krishnamachari członka indyjskiej komisji planowania z 22 listopada 1955 r. http://www.php.isn.ethz.ch/collections/coll_india/NehruYears-Introduction. cfm?navinfo $=9631$. 
[35] Raport ambasadora Indii w Moskwie Menona z 5 stycznia 1961 r., http://www.php. isn.ethz.ch/collections/coll_india/NehruYears-Introduction.cfm?navinfo=9631.

[36] Raport Menona ambasadora w Moskwie z 5 stycznia 1961 r. http://www.php.isn. ethz.ch/collections/coll_india/NehruYears-Introduction.cfm?navinfo=9631.

[37] The Sino-Indian Border Dispute. Section 3: 1961-1962, DD/I Staff Study, CIA/RSS, Reference Title Polo XVI, 5 May 1964, www.foia.cia.gov/CPE/POLO/polo-09.pdf.

[38] Telegram from the Departament of State to the Embassy In India, 28 October 1962, http://www.state.gov/r/pa/ho/frus/kennedyjf/46453.htm, s. 187.

\section{INDIAN-RUSSIAN RELATIONS IN 50S AND60S IN XXTH CENTURY}

Expansive neighbour policy - Pakistan and PRC - was determining J. Nehru-the leader of India- to make an alliance which would ensure the safety guarantee to his country. Although the active and favorable policy of Washington for India, more realistic was the alliance with Moscow. The Soviets pointed the importance of Indian leadership in the Movement of non-aligned Countries. Except of political assumptions about contact intensification with Country of Councils, the economical aspect was the most important. The main aim of an internal policy was to get the country off the civilization collapse. It wouldn't be able without the foreign assurance of funding and investments. At the same time India had to be politically independent country, that is why The economic aid had to be limited only to economical aspect. After analyzing many aspects foreign diplomats finally accepted the USSR offer for India. Its assumption was to build some heavy industry, rafineries, pharmaceutical company and scientific and research institutions. All of it was thanks to the financial help and technological thought of USSR. As a result of Pakistani agreement with the West, Moscow started supporting Indian claims against Kashmir. On the eve of armed confrontation with Chinese army the Indian neutralism was subjected to a serious attempt. India couldn't even count on the moral support of Moscow, which in the future conflict with India, was decided to support PRC. Thanks to the support the Indian armed forces by the USA and USSR, Indian prestigious defeat in confrontation with China, resulted in reorganization and additional investment. In the result of those moves inevitably approaching confrontation with Pakistan had a really big chance to end in a real success for India.

Keywords: Jawaharlal Nehru, India, Soviet Union, Nikita Khrushchev, Non-Aligned Movement.

DOI: $10.7862 /$ rz.2017.hss.70

Przestano do redakcji: sierpień 2017 r.

Przyjęto do druku: grudzień 2017 r. 
